\title{
Light-evoked Expansion of Subretinal Space Volume in the Retina of the Frog
}

\author{
Bo Huanga and Chester J. Karwoski \\ Vision Research Laboratory, Department of Psychology, University of Georgia, Athens, Georgia 30602
}

\begin{abstract}
The retina of the frog was superfused with a Ringer solution containing impermeant "probe" cations and anions. Lightevoked concentration changes in these probe ions were measured in the subretinal space (SRS) with ion-selective microelectrodes. A decrease in probe ion concentration was found, and several observations suggest that this is caused by a light-evoked expansion of the SRS. The probe ion decrease was not seen in the isolated retina; thus, the pigment epithelial (PE) cells are important for its generation. Pharmacological studies suggest that $\mathrm{K}^{+}$channels in the $\mathrm{PE}$ cells are important-perhaps the PE cells shrink in response to the light-evoked decrease in SRS [K+]. The light-evoked decrease of SRS volume may be important in the understanding of SRS solute concentrations, retina-PE adhesivity, photoreceptor-PE cell interactions, and the interphotoreceptor matrix.
\end{abstract}

Studies using a variety of experimental approaches have found that the volume of extracellular space (ECS) in the nervous system can change in certain situations. Perhaps the first to report a change in ECS volume was Van Harreveld and Khattab (1967), who used electron microscopy to show that ECS decreased during spreading depression. In recent years, changes in ECS volume in living tissue have been measured rapidly, and continuously as a function of time, by a technique using impermeant ions and ion-selective microelectrodes (ISMs; developed by Phillips and Nicholson, 1979; Dietzel et al., 1980; Nicholson and Phillips, 1981). Studies using this and other techniques have shown that ECS volume can change by up to $50 \%$ during relatively severe treatments such as spreading depression, seizure activity, direct electrical stimulation of input nerves, anoxia, and application of high doses of neuroactive substances or of substances that shift extracellular osmolarity (reviewed by Svoboda and Sykova, 1991).

Less is known about whether ECS volume changes during the normal course of neural activity. In the retina of an invertebrate (the honeybee drone), a series of intense light flashes leads to a $20-30 \%$ decrease in ECS volume (Orkand et al., 1984; Ziegler and Walz, 1989). Simultaneously, extracellular calcium con-

\footnotetext{
Received Feb. 26, 1992; revised May 26, 1992; accepted May 29, 1992.

This research was funded in part by NIH Grant EY-03526. We thank Drs. Jonathan Coles and Roy Steinberg for their support and help in the early phases of this research, and Drs. Joseph Adorante, Beth Burnside, and Sheldon Miller for useful discussions.

Correspondence should be addressed to Chester J. Karwoski at the above address.

Present address: Department of Biology, 0322, University California at San Diego, La Jolla, CA 92093.

Copyright (C) 1992 Society for Neuroscience $0270-6474 / 92 / 124243-10 \$ 05.00 / 0$
}

centration $\left(\left[\mathrm{Ca}^{2+}\right]_{o}\right)$ increases up to $30 \%$, a result suggesting that a significant percentage of the $\mathrm{Ca}$ increase is due to the ECS shrinkage. In a vertebrate (rat), ECS volume in the spinal cord decreases up to $50 \%$ in response to neural activity resulting from an injury to the hind paw (Svoboda and Sykova, 1989; 1991).

In the present article, we present evidence that light evokes an increase in ECS volume in the subretinal space (SRS) of frog retina. The SRS is the extracellular region between the photoreceptor outer segments and the apical processes of the pigment epithelial (PE) cells.

Some of our results have been published in abstract form (Huang and Karwoski, 1989, 1990), and some related results can be found in another article from our laboratory (Xu et al., 1991). One other study has used a similar technique to measure changes in ECS volume in the vertebrate retina-this was by DoCarmo and Martins-Ferreira (1984), who measured changes during spreading depression in chick retina.

\section{Materials and Methods}

In large part, the preparation, solutions, light stimulus, recording electrodes, and general procedures were identical to those reported by $\mathrm{Xu}$ et al (1991). In addition, the methods are presented in complete detail in Huang (1991). In brief, light-evoked responses were recorded from the retinas of frogs (Rana pipiens). Usually, the retina-in-eyecup was used, but isolated retinas (receptor side up) were used in some experiments. The preparation was superfused with an amphibian Ringer's solution (composition, in mM: $82.5 \mathrm{NaCl}, 27.5 \mathrm{NaHCO}_{3}, 2.5 \mathrm{KCl}, 1.8$ $\mathrm{CaCl}_{2}, 1.0 \mathrm{MgCl}_{2}, 10.0$ glucose, bubbled with $95 \% \mathrm{O}_{2}, 5 \% \mathrm{CO}_{2}$ ), to which pharmacological agents could be added. Extracellular responses (field potentials and ionic changes) were measured with double-barreled ion-selective microelectrodes (ISMs). In some experiments, extracellular resistance was measured between two pipettes whose tips were located at different depths within the SRS.

In most experiments, the tip of the ISM was positioned in the SRS. The SRS was identified in an experiment by functional criteria discussed in Karwoski et al. (1985). The light-evoked extracellular potential at this depth is called the local electroretinogram (LERG). It was recorded by the Ringer-filled reference barrel of the ISM relative to a Ringerfilled pipette located in the superfusate.

The retina was stimulated with diffuse flashes of white light. Usually, stimulus duration was $94 \mathrm{sec}$, and the dark interval was $150 \mathrm{sec}$. The maximum light intensity was $3.2 \times 10^{6} \mathrm{lux}$, which for convenience is equated to $10 \log$ units. Stimulus intensity was usually set at $7 \log$ units.

Techniques for measuring ECS changes. The technique of using extracellular probe ions to measure changes in ECS was described by Nicholson and Phillips (1981). In general, the retina is superfused with an ion that (1) will readily diffuse through extracellular space, (2) will not move intracellularly, and (3) can be measured by an ion-selective microelectrode. The first and third of the these requirements are met by the cations tetramethylammonium $\left(\mathrm{TMA}^{+}\right.$) and tetraethylammonium $\left(\mathrm{TEA}^{+}\right)$, and by the anions hexafluorarsenate $\left(\mathrm{AsF}_{5}{ }^{-}\right)$and $\alpha$-naphthalene sulfonate $\left(\alpha-\mathrm{NS}^{-}\right)$. The second requirement is known not to hold for $\mathrm{TMA}^{+}$, and it is uncertain for the other three probe ions. The extent to which this affects interpretation of the results is considered below in both the Results and Discussion. 


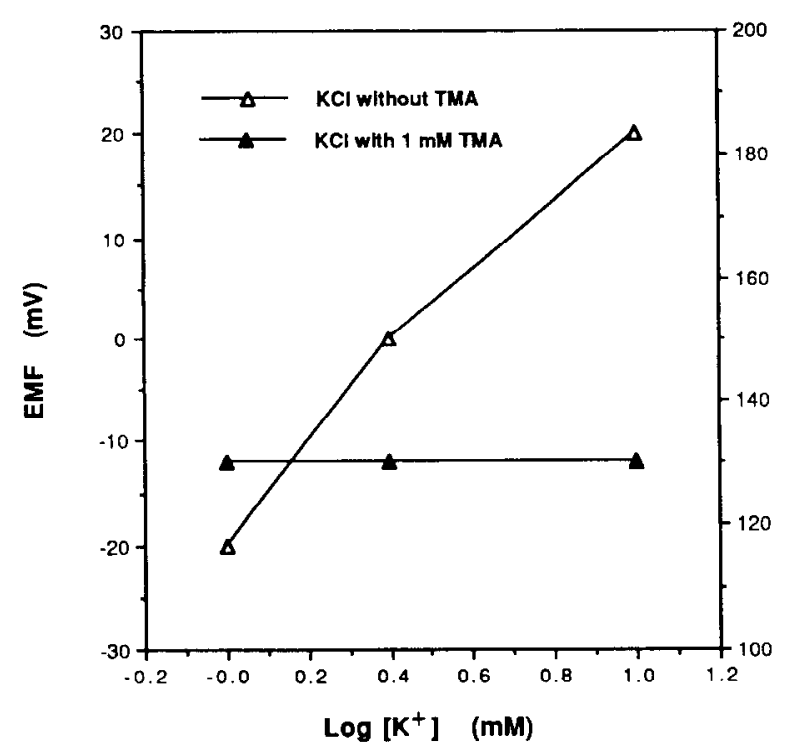

Figure 1. A typical calibration curve for an ISM containing the Corning exchanger to changes in $\left[\mathrm{K}^{+}\right]$with and without a background of $1.0 \mathrm{mM}$ $\mathrm{TMA}^{+}$. When TMA ${ }^{+}$is present (solid triangles), the right ordinate shows voltage. When $\mathrm{TMA}^{+}$is not present (open triangles), the left ordinate applies. Concentrations of $\mathrm{K}^{+}$tested were $1.0,2.5$, and $10.0 \mathrm{mM}$. Note that when 1.0 $\mathrm{TMA}^{+}$was applied, the output voltage of the electrode shifted about $130 \mathrm{mV}$ and the electrode no longer responded to changes in $\left[\mathrm{K}^{+}\right]$.

The ISMs were fabricated from double-barreled Omega-dot glass tubing (Glass Company of America, Bargaintown, NJ), with their tips beveled such that the diameter of the unbeveled part was $2-5 \mu \mathrm{m}$. The cations were measured with the classical $\mathrm{K}^{+}$exchanger (Corning, 477317), and the anions with an exchanger consisting of crystal violet dissolved in 3-nitro- $O$-xylene (Nicholson and Phillips, 1981). The ISMs containing the Corning exchanger responded to $\mathrm{K}^{+}$but were more sensitive to $\mathrm{TMA}^{+}$and TEA ${ }^{+}$(see below). In some experiments, a liquid membrane based on valinomycin (Fluka, 60031) was used, because these ISMs retained $\mathrm{K}^{+}$sensitivity in the presence of the probe cations. For all ISMs, after ion-selective resin was introduced into the active barrel, the active barrel was then backfilled with a simplified Ringer's solution

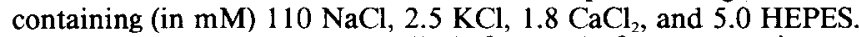

ISMs were calibrated, normally before and after an experiment, in solutions containing the probe ion (ranging from 0.1 to $1.0 \mathrm{mM}$ ) and fixed concentrations of $\mathrm{NaCl}(110 \mathrm{mM}), \mathrm{KCl}(2.5 \mathrm{mM})$, and HEPES $(10 \mathrm{mM})$. For both cation- and anion-sensitive ISMs, the ISM responded with an approximately Nernstian slope for probe ion concentrations betwecn 0.1 and $10.0 \mathrm{mM}$.

In addition, the Corning electrodes were tested for their sensitivity to $\mathrm{K}^{+}$in the presence of probe ions. The electrode voltage shifted about $40 \mathrm{mV}$ when $\left[\mathrm{K}^{+}\right]$was changed from 1.0 to $10.0 \mathrm{mM}$ in the absence of the probe ion (Fig. 1, open triangles), but the electrode no longer responded to $\mathrm{K}^{+}$when $1.0 \mathrm{mM}^{\mathrm{TMA}}{ }^{+}$was also present (Fig. 1, solid triangles). Thus, Corning electrodes respond to $\mathrm{K}^{+}$in the absence of $\mathrm{TMA}^{+}$or $\mathrm{TEA}^{+}$, but $\left[\mathrm{K}^{+}\right]$does not noticeably contribute to the response when these probe ions are present. Additional details about the electrodes can be found in Huang (1991).

In an experiment, control field potentials and ion responses were obtained prior to application of the probe inn. The probe ion was added to the superfusate, and it took 30-60 min for its concentration within the SRS to reach a level that was sufficiently stable that light-evoked responses could be accurately measured. This value averaged about $50 \%$ of the concentration in the superfusate. After $1-2 \mathrm{hr}$, this value reached $80-90 \%$, and it reached $100 \%$ at $5-6 \mathrm{hr}$. This long equilibration time may be related to a residual $0.5-1.0 \mathrm{~mm}$ of vitreous humor remaining over the retina; this vitreous serves as an unstirred layer, and this slows diffusion of probe ions toward the retina. A second factor is that there is a well of Ringer's solution between the back of the eyecup and an $\mathrm{Ag} / \mathrm{AgCl}$ pellet that serves as a ground; this well (a "thick, stagnant pool," in the terminology of Nicholson and Hounsgard, 1983) serves as a sink for any substance diffusing through the retina and thus length- ens equilibration time within the retina. Lastly, equilibrium will be slowed if there exists substantial intracellular uptake of the probe ions.

Assuming that the probe ions are largely restricted to ECS, and that there is no light-evoked change in any probe ion uptake mechanism, then the light-evoked changes in ECS volume can be calculated from changes in probe ion concentrations. The relationship has been described by Dietzel et al. (1980) and is expressed as

$$
\begin{aligned}
& \text { percentage change of ECS volume } \\
& =\left(1-\frac{\text { [probe ion] before light }}{\text { [probe ion] after light }}\right) \times 100 .
\end{aligned}
$$

\section{Results}

\section{Basic observations}

Probe cations. In the SRS, light induced a gradual decrease in the concentration of $\mathrm{TMA}^{+}$and $\mathrm{TEA}^{+}$, and there was a gradual return in concentration at light offset. Typical responses are shown in Figure 2. Here, prior to application of the probe ions, the ISM recorded the well-known light-evoked $\mathrm{K}^{+}$decrease of the SRS. The probe ion decrease does not reach full amplitude until at least $1.0 \mathrm{~min}$ of light, and it is thus significantly slower than the $\mathrm{K}^{+}$decrease.

The simultaneously recorded field potential, LERG, consists of the $b$-wave (initial negative-going transient) and the c-wave (slow positive-going shift in basclinc), followed by the ncgativc d-wave complex at light offset. The probe cations exert only minor effects on the LERG. This indicates that the retina is probably still responding to light in a normal fashion. Supporting this is the observation that the SRS $\mathrm{K}^{+}$decrease, when recorded with valinomycin-based ISMs, shows normal amplitude and waveform during the probe cation application (see Figs. 8, 9). Thus, the light-evoked probe cation decrease is indicative of a process normally occurring in the retina.

Probe anions. Light also induced a gradual decrease in the concentrations of $\mathrm{AsF}_{6}{ }^{-}$and $\alpha-\mathrm{NS}^{-}$(Fig. 3). Here, prior to probe ion application, the ISM recorded no clear response, presumably because the ISM was not very sensitive to any endogenous anion whose concentration varied. The probe ion decreases had properties similar to those of the cations (Fig. 2). Also, like the cations, the probe anions had no major effect on the LERG.

Probe ion summary. The data obtained both with probe cations and with anions are summarized in Table 1 . The first data column shows the time-to-peak of the responses. For the standard $94 \mathrm{sec}$ light stimulus, the $\mathrm{TMA}^{+}$response often did not quite reach maximum amplitude by light offset. Therefore, in Table 1 , only $\mathrm{TMA}^{+}$data obtained with a 10 min light stimulus (see below) are presented. Responses of the other probe ions peaked within $94 \mathrm{sec}$ or reached a peak al aboul $94 \mathrm{sec}$. Timeto-peak averaged $107 \mathrm{sec}$ for $\mathrm{TMA}^{+}$but only about $80 \mathrm{sec}$ for the other probe ions. An ANOVA showed a significant difference in this parameter across probe ions, and Tukey's multiple comparison test showed that the $\mathrm{TMA}^{+}$response had a longer timeto-peak $(p<0.01)$.

The second data column of Table 1 presents response amplitude, expressed as the probe ion concentration during the peak of the response relative to the resting concentration. Although in all cases this value was between $92 \%$ and $95 \%$, the ANOVA showed significant differences $(p<0.01)$ and Tukey's multiple comparison test showed that the $\mathrm{TMA}^{+}$and $\mathrm{AsF}_{6}{ }^{-}$ responses were significantly greater than that of TEA ${ }^{+}$and $\alpha-\mathrm{NS}^{-}$. The third data column shows how the probe ion responses convert to changes in ECS volume, specifically in the volume of 


\section{CATION PROBES}

Control

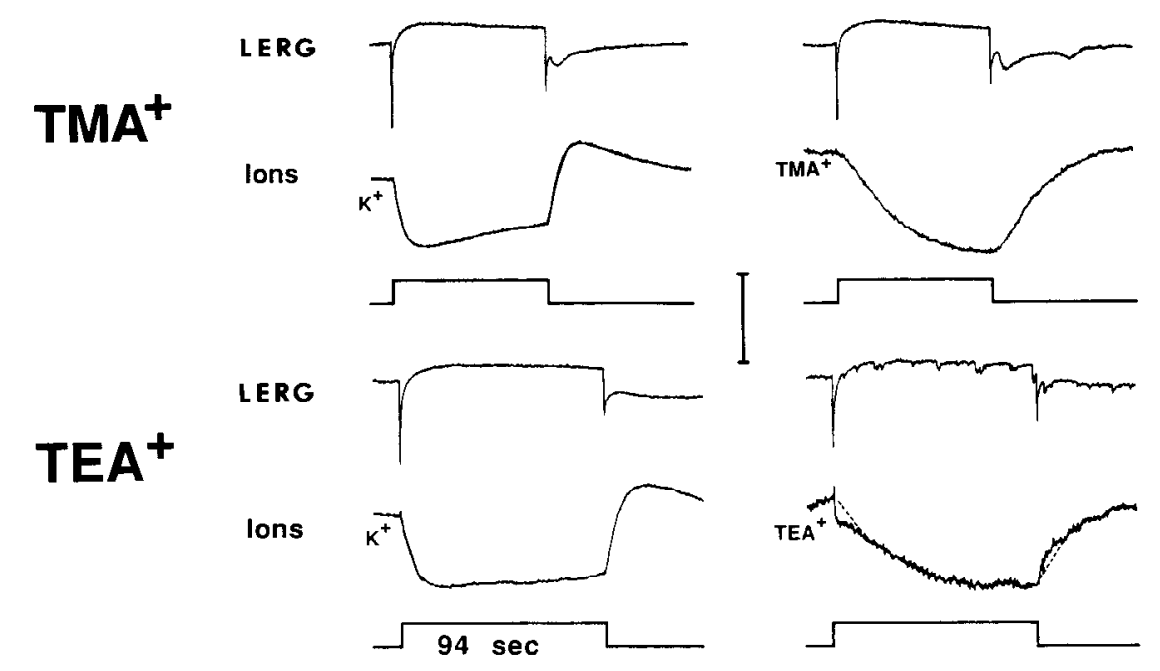

Figure 2. Light-evoked LERGs and changes in concentrations of $\mathrm{K}^{+}$and of the probe cations $\mathrm{TMA}^{+}$and TEA+ in the SRS. Superfusate concentrations of TMA ${ }^{+}$and TEA ${ }^{+}$were 10.0 and $1.0 \mathrm{mM}$, respectively. Control, responses before probe cation superfusion; Prohe, responses during probe cation superfusion; Ions, ionic responses consisting of $\mathrm{K}^{+}$in control conditions, and of probe cations during superfusion with these cations. Responses were evoked with diffuse light $(3.0 \mathrm{~mm})$ of intensity $\log 7\left(3.2 \times 10^{3} \mathrm{lux}\right)$. The ordinate of the ionic responses in this and all following figures has been converted to millimolar concentration and linearized. Baseline levels (in mM): $\mathrm{K}^{+}, 2.5 ; \mathrm{TMA}^{+}, 4.7$; TEA ${ }^{+}, 0.1$. The resting level of $\mathrm{TEA}^{+}$was especially low, because TEA ${ }^{+}$has a progressively severe effect on the retina, and thus TEA ${ }^{+}$responses had to be obtained before a steady-state TEA+ concentration level was achieved in the SRS. Calibration: $L E R G, 2.3 \mathrm{mV} ; K^{+}, 0.5 \mathrm{mM} ; T M A^{+}, 0.3 \mathrm{mM} ; T E A^{+}, 0.007$ mM. In the TEA' recording (lower right), a field potential differencing artifact (Vogel, 1980) exists, and the broken line indicates where we believe the potential should be.

\section{ANION PROBES}

\section{Control}

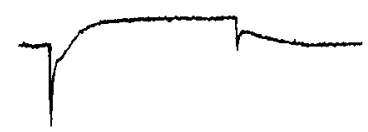

LERG

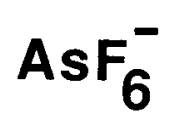

lons
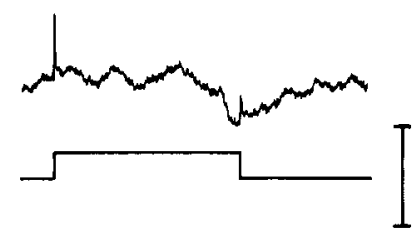

LERG

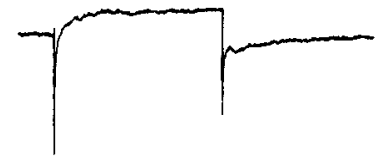

lons

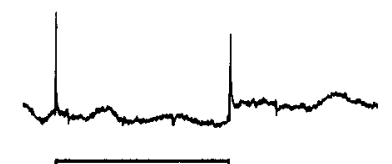

Probe
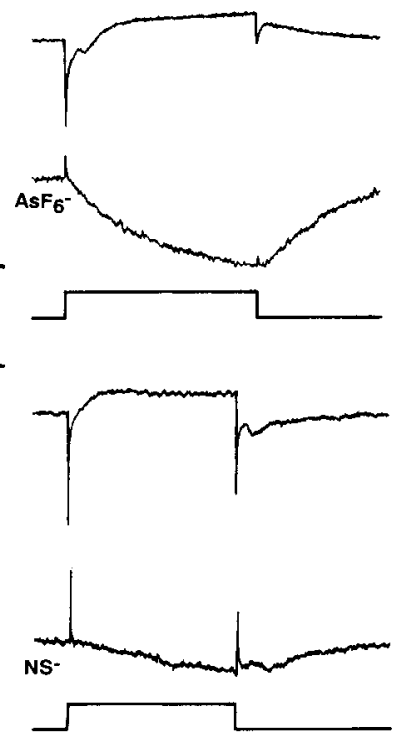

Figure 3. Light-cvoked LERGs and changes in concentration of probe anions, $\mathrm{AsF}_{6}^{-}$and $\alpha-\mathrm{NS}^{-}$, in the SRS. The concentrations of both $\mathrm{AsF}_{6}-$ and $\alpha$ $\mathrm{NS}^{-}$were $1.0 \mathrm{mM}$ in the superfusate. Other details are as in Figure 2. Baseline levels are $0.5 \mathrm{mM}$ for $\mathrm{AsF}_{6}{ }^{-}$and 0.1 mM for $\alpha$-NS ${ }^{-}$. Calibration: $L E R G, 2.0$ $\mathrm{mV} ; A s F_{6}^{-}, 0.07 \mathrm{mM} ; \alpha-N S^{-}, 0.006$ $\mathrm{mM}$. 
Table 1. Summary table of light-evoked decreases in probe ion concentrations in the SRS

\begin{tabular}{llll} 
Probe ion & $\begin{array}{l}\text { Time-to-peak } \\
(\mathrm{sec})\end{array}$ & $\begin{array}{l}\text { Peak decrease } \\
(\%)\end{array}$ & $\begin{array}{l}\Delta \text { SRS } \\
(\%)\end{array}$ \\
\hline TMA $^{+}$ & $107 \pm 10$ & $93 \pm 1$ & $7 \pm 1$ \\
& $(n=7)$ & $(n=10)$ & $(n=10)$ \\
TEA $^{+}$ & $78 \pm 7$ & $95 \pm 1$ & $5 \pm 1$ \\
& $(n=7)$ & $(n=4)$ & $(n=4)$ \\
AsF $_{6}^{-}$ & $73 \pm 7$ & $92 \pm 1$ & $9 \pm 1$ \\
& $(n=12)$ & $(n=12)$ & $(n=12)$ \\
$\alpha$-NS $^{-}$ & $80 \pm 6$ & $95 \pm 1$ & $5 \pm 2$ \\
& $(n=6)$ & $(n=4)$ & $(n=4)$
\end{tabular}

Units: time-to-peak, seconds after light onset; peak decrease, minimum percentage of prelight baseline concentration; $\triangle$ SRS, percentage change in SRS volume. All values are mean $\pm \mathrm{SD}$

the SRS. The results from all probe ions suggest that SRS expands by $5-9 \%$.

Although useful data were obtained with all probe ions, some did present problems. Specifically, TEA+ produced spontaneous baseline shifts (Fig. 2), prior to it depressing LERG amplitude. Also, $\alpha-\mathrm{NS}^{-}$depressed the LERG; therefore, observations with it were done quickly, in many cases before its concentration in the SRS reached equilibrium (Fig. 3). Therefore, the retina may be "healthier" during $\mathrm{TMA}^{+}$and $\mathrm{AsF}_{6}{ }^{-}$, and the larger response amplitudes obtained with these may be more trustworthy. At any rate, more experiments were done with these two probe ions (Table 1), because retinal responses were more stable. Lastly, during prolonged application of $\mathrm{AsF}_{6}-$, light flashes sometimes evoked a spreading depression. Because $\mathrm{TMA}^{+}$seemed to have no deleterious effect, its responses were studied most intensively.
Stimulus intensity. As shown in Figure 4, all light intensities evoked a TMA ${ }^{+}$decrease in the SRS. A very weak response was seen at an intensity of $5 \log$ units, and this converted to a $0.60 \%$ increase in SRS volume. Increasing intensities led to increasing $\mathrm{TMA}^{+}$responses and increasing SRS volume changes, but responses reached a maximum at about $8 \log$ units. The intensity routinely used in this study $(7 \mathrm{log})$ is about $2 \log$ above response threshold, and it gave a large, but not saturating, response.

\section{Light-evoked uptake}

Although it has been assumed that the light-evoked decrease in probe ion concentration in the SRS is due to an expansion of SRS volume, other explanations are possible. The most serious alternative explanation is that there is a resting uptake of probe ions into some cell(s) and that the rate of this uptake is increased during light presentation. Arguing against this is that the SRS probe ion response shows the same polarity, and similar amplitude and time course, either with probe cations or with anions. Although TMA ${ }^{+}$enters retinal cells (Adorante and Miller, 1990), it is unlikely that the TMA+ uptake mechanism is tightly coupled with an uptake mechanism for the anions $\mathrm{AsF}_{6}{ }^{-}$and $\alpha$ NS $^{-}$(see Discussion). There are two other observations that support the existence of an expansion of SRS volume.

Long-duration light stimulation. If SRS volume increases in a step fashion and remains increased indefinitely during prolonged illumination, then [TMA ${ }^{+}$] in the SRS will initially be decreased, but it should gradually reequilibrate to its baseline level, because of $\mathrm{TMA}^{+}$diffusion from proximal retina to SRS. Failure to show such reequilibration would suggest the existence of some other process, such as a light-evoked change in probe ion uptake.

Figure 5 shows an example of a $\mathrm{TMA}^{+}$response, and of a $\mathrm{K}^{+}$

\section{$\left[\mathrm{TMA}^{+}\right]$}

\section{$\log I$}

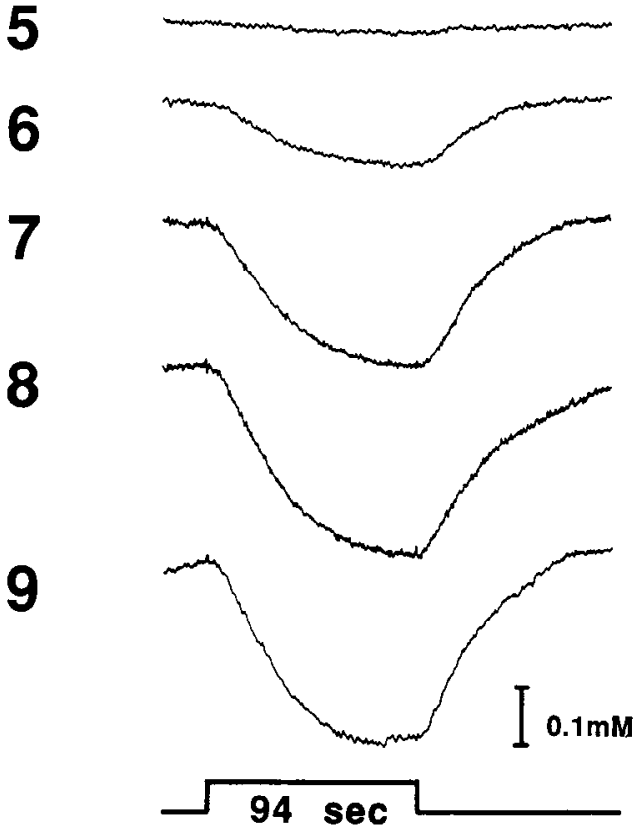

\section{ECS}

Figure 4. Light-evoked changes in [TMA $\left.{ }^{+}\right]$and ECS as a function of light intensity $\left(\log I\right.$ of $\left.10=3.2 \times 10^{6} \mathrm{lux}\right)$. The percentage change of ECS volume was calculated by Equation 1 (Materials and Methods). In the ECS plots, an upward shift corresponds to an expansion of ECS volume. Superfusate [TMA ${ }^{+}$] was $10.0 \mathrm{mM}$. Baseline [TMA $\left.{ }^{+}\right]$in the SRS was $5.3 \mathrm{mM}$; baseline ECS $=100 \%$.

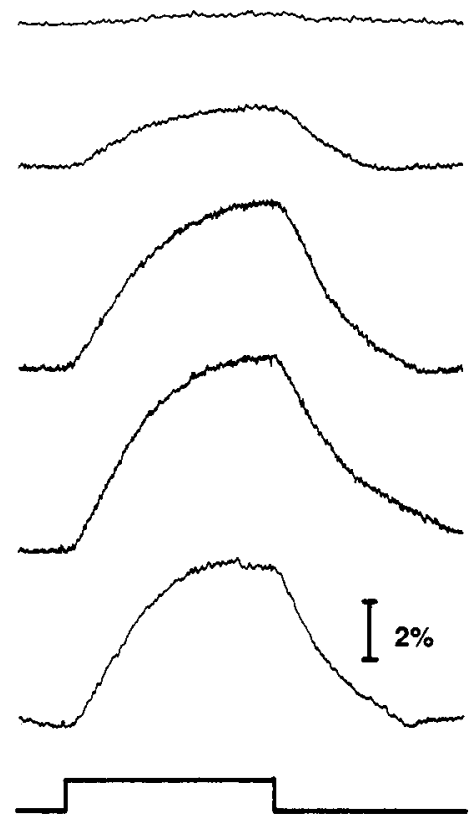




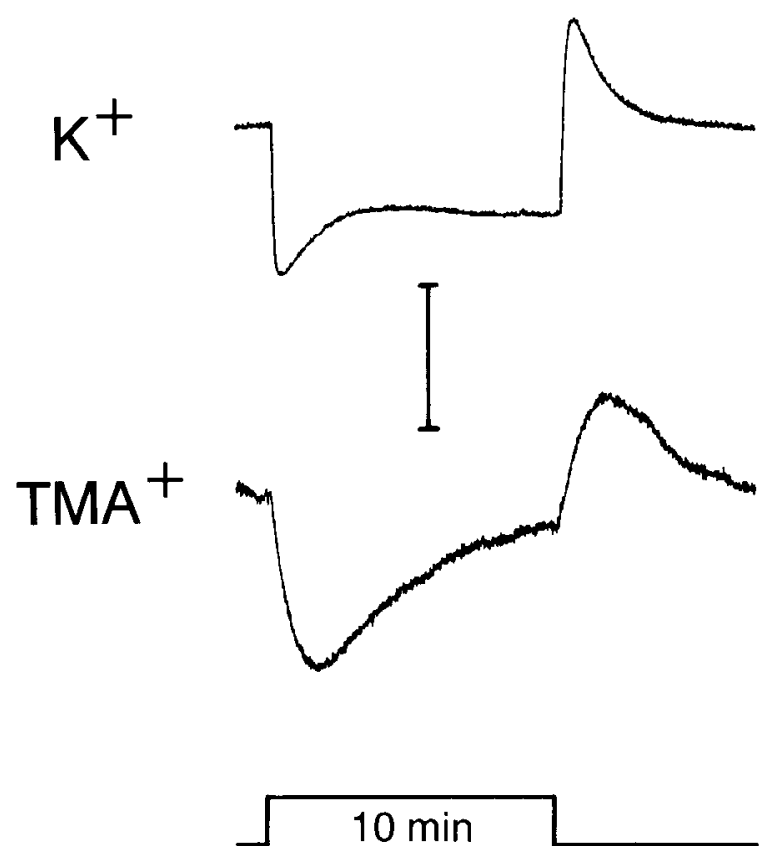

Figure 5. Light-evoked changes in $\left[\mathrm{K}^{+}\right]$and $\left[\mathrm{TMA}^{+}\right]$in the SRS during a long-duration $(10 \mathrm{~min})$ light flash. Superfusate $\mathrm{TMA}^{+}$concentration was $10.0 \mathrm{mM}$. Baseline levels in the SRS were $2.5 \mathrm{mM}$ for $\mathrm{K}^{+}$and 7.3 $\mathrm{mM}$ for TMA ${ }^{+}$. Calibration: $K^{+}, 1.1 \mathrm{mM} ; T M A^{+}, 0.2 \mathrm{mM}$.

response, to a $10 \mathrm{~min}$ light presentation. The $\left[\mathrm{TMA}^{+}\right]$decreased to $93.4 \pm 1.3 \%$ (mean $\pm \mathrm{SD} ; N=10$ ) of its prelight baseline concentration. However, with continued illumination, [TMA $\left.{ }^{+}\right]$ gradually returned, reaching $98.9 \pm 0.8 \%$ of the original baseline concentration. At light offset, there was a transient increase of $\left[\mathrm{TMA}^{+}\right]$to a maximum level that was higher than baseline.

On the other hand, the light-evoked decrease of $\left[\mathrm{K}^{+}\right]$in the SRS did not show such a substantial recovery during continued illumination (Fig. 5). The $\left[\mathrm{K}^{+}\right]_{o}$ initially decreased to $74.3 \pm$ $4.6 \%(N=7)$ of its baseline concentration, and recovered to only $84.5 \pm 3.1 \%$ during light. Because $\left[\mathrm{K}^{+}\right]$returns less than halfway toward baseline, there must be during light a sustained shift in the movement of $\mathrm{K}^{+}$across cell membranes. This contrasts to the nearly complete recovery observed with $\left[\mathrm{TMA}^{+}\right]$ (scc also Li ct al., 1992).

Resistance measurements. If SRS volume increases during light, then resistance across the SRS should decrease. Initial attempts to measure any light-evoked resistance changes were unsuccessful. This was because SRS resistance is low (Karwoski et al., 1985) and current-evoked voltage signals were difficult to detect in the background noise. Also, slight drift in signal amplitude tended to obscure small light-evoked changes. In the frog retina, aspartate is known to cause swelling of cells, shrinkage of ECS, and enhanced light-evoked changes in [TMA ${ }^{+}$in the SRS (Xu et al., 1991). Current-evoked voltage signals are significantly larger after aspartate. Thus, measurements of lightevoked changes in SRS resistance were attempted during application of aspartate $(30 \mathrm{mM})$.

During light, resistance across the SRS in retinas superfused with aspartate gradually dropped to $91.3 \pm 1.7 \%(N=5)$ of its prelight baseline level. An example is shown in Figure 6, where resistance decreased initially down to $92 \%$ of baseline, but then stabilized at $95 \%$. In this retina, at light offset, resistance transiently rose to a value higher than baseline, before returning

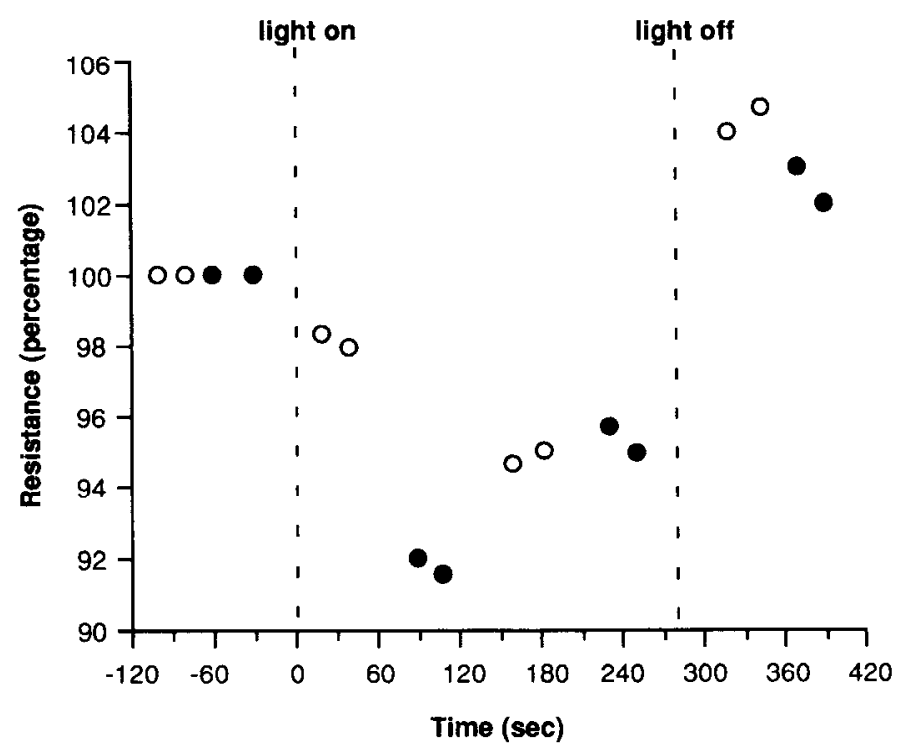

Figure 6. Resistance across the SRS during light. Measurements are normalized such that the prelight level $=100 \%$. The current pulses used to measure resistance had a strength of $20 \mu \mathrm{A}$ and duration of $1.25 \mathrm{sec}$. Solid circles, measurements for current passed across the retina from vitreal surface to pigment epithelium; open circles, measurements for current pulses of the opposite direction. Light was turned on at $0 \mathrm{sec}$ and off at $280 \mathrm{sec}$.

toward control levels, but this offset overshoot was seen in only one other retina. The decreased resistance during light is compatible with an increase in SRS volume.

\section{Isolated retina}

In order to test whether the PE cells play a role in the lightevoked decrease in [TMA ${ }^{\dagger}$, we used the isolated retina preparation, in which the choroid and PE cells are removed from the neural retina. Typical ionic recordings from within the layer of photoreceptor outer segments of an isolated retina are shown in Figure 7. The ECS around the outer segments is large in the isolated retina, and this would be expected to reduce any lightevoked concentration changes. However, a strong light-evoked $\mathrm{K}^{+}$decrease was still observed (Fig. 7, top row). Light-evoked $\mathrm{Ca}^{2+}$ responses could also be observed (Livsey et al., 1990). However, the $\mathrm{TMA}^{+}$decrease was absent, and instead a small increase in $\left[\mathrm{TMA}^{+}\right]$was observed (second row). (Note that the vertical gain in this record is high.) In four preparations, light evoked an increase in $\left[\mathrm{TMA}^{+}\right]$to $100.33 \pm 0.10 \%$ of baseline level, which would convert to a $0.33 \%$ decrease in ECS volume. This failure to record a $\mathrm{TMA}^{+}$decrease in the isolated retina suggests that the PE cells play a critical role in its generation.

\section{Pharmacological studies}

Blockers of synaptic transmission. In a previous report (Xu et al., 1991), we showed that aspartate and also the combination of aminophosphonobutyric and kynurenic acids both substantially block synaptic transmission from photoreceptors to postsynaptic neurons. In that same study, we also showed that these agents did not depress the light-evoked decreases of $\mathrm{K}^{+}$or of $\mathrm{TMA}^{+}$in the SRS. This result indicates that neurons postsynaptic to the photoreceptors play no significant role in the TMA ${ }^{+}$ decrease, thus further supporting the importance of the role of the PE.

If it is assumed that the PE cells shrink during light stimu- 


\section{LERG}

\section{Control}

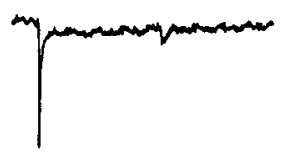

TMA ${ }^{+}$

Recovery

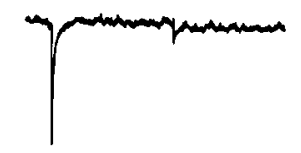

T

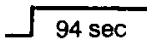

\section{lons}
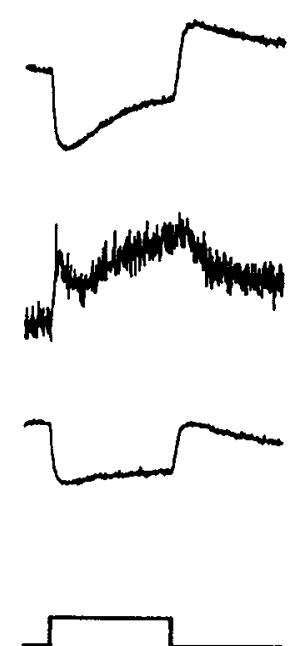

Figure 7. Light-evoked changes in $\left[\mathrm{TMA}^{+}\right]$near the photoreceptor outer segments in the isolated retina. Superfusate [TMA+] was $10 \mathrm{mM}$. Baseline levels (in $\mathrm{mM}$ ) at the photoreceptors: $\mathrm{K}^{+}, 2.5$; $\mathrm{TMA}^{+}, 10.0$. Note that in the isolated retina, TMA ${ }^{+}$baseline concentration near the photoreceptor outer segments was equal to its superfusate concentration. Also, note that for control and recovery responses, the ion response is $\mathrm{K}^{+}$, but when $\mathrm{TMA}^{+}$was applied, the ion response becomes a $\mathrm{TMA}^{+}$ response. Calibration: $L E R G, 0.54 \mathrm{mV} ; T M A^{+}, 0.04 \mathrm{mM} ; K^{+}, 0.35$ $\mathrm{mM}$. The sharp, initial upward deflection at lights on in the TMA+ ion response is a field potential differencing artifact, and it is visible in this trace because the gain is so high.

lation, thereby leading to an increase in SRS volume, then it is of interest to specify the membrane mechanisms in the PE cells that underlie these events. To this end, a number of pharmacological agents were applied that interfere with specific features of PE membrane function. In interpreting results from these experiments, the light-evoked SRS $\mathrm{K}^{+}$decrease was monitored carcfully. If this response was not decreased by the agent, then it was assumed that light-evoked photoreceptor responses were

present and somewhat normal. Therefore, any simultaneous depression of the light-evoked $\mathrm{TMA}^{+}$decrease likely was due to effects on the PE cells, rather than on the photoreceptors.

Barium $\left(\mathrm{Ba}^{2+}\right) . \mathrm{Ba}^{2+}$ is a blocker of $\mathrm{K}^{+}$channels in retinal cells including the glia (Karwoski et al., 1989; Newman, 1989) and the PE (Griff et al., 1985). Concentrations of $\mathrm{Ba}^{2+}$ ranging from 50 to $500 \mu \mathrm{M}$ were added to Ringer solutions containing 5-10 $\mathrm{mM}^{\mathrm{TMA}^{+}}$. In Figure 8 (left column), $\mathrm{Ba}^{2+}(100 \mu \mathrm{M})$ depressed the LERG b-wave, which is thought to result from responses of the Müller cells to changes in $\left[\mathrm{K}^{+}\right]_{\mathrm{o}}$, and it also depressed the c-wave, which results from responses of the $P E$ and Müller cells to the light-evoked decrease in $\left[\mathrm{K}^{+}\right]$in the SRS. Simultaneously, the SRS $\mathrm{K}^{+}$decrease (middle column) was enhanced by $\mathrm{Ba}^{2+}$ (Oakley et al., 1991), while the $\mathrm{TMA}^{+}$decrease was depressed (right column). In five preparations, $\mathrm{Ba}^{2+}$ reduced the TMA response to $35.8 \pm 13.6 \%$ of control levels. The effect was almost fully reversible (Huang, 1991). At $500 \mu \mathrm{M}, \mathrm{Ba}^{2+}$ had stronger and less reversible effects, while $50 \mu \mathrm{M} \mathrm{Ba}^{2+}$ had weaker, but fully reversible, effects.

These results suggest a role of $\mathrm{K}^{+}$channels in the light-evoked expansion of the SRS volume. These channels are likely to be the $\mathrm{Ba}^{2+}$-sensitive $\mathrm{K}^{+}$conductance in the apical membrane of the PE cells (Hughes and Steinberg, 1990).

Amiloride. Amiloride is a blocker of the $\mathrm{Na}^{+}-\mathrm{H}^{+}$exchanger in a variety of cells (Hoffmann and Simonsen, 1989). It was used in the present experiment to explore the contribution of this exchanger to the light-evoked expansion of SRS volume. As shown in Figure 9, amiloride $(2.0 \mathrm{mM})$ depressed the LERG b-, c-, and d-waves, and it also attenuated the SRS TMA+ decrease to $46 \pm 6 \%$ of control value. It also slowed down the SRS K ${ }^{+}$decrease, but did not significantly affect the amplitude at long time periods. This latter observation suggests that the photoreceptors are working almost normally in some respects. Thus, it is possible that a functioning, amiloride-sensitive, $\mathrm{Na}^{+}-$ $\mathrm{H}^{+}$exchanger in the PE cells is necessary for these cells to respond during light, which results in an expansion of SRS volume (see Huang, 1991, for details).

\section{LERG}

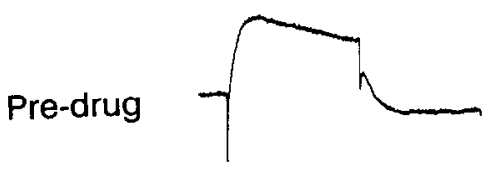

$$
\mathrm{Ba}^{2+}
$$

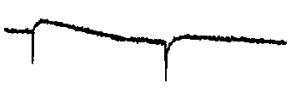

TMA light-evoked LERG, $\mathrm{K}^{+}$, and ate $\left[\mathrm{TMA}^{+}\right]$was $10 \mathrm{mM}$. TMA ${ }^{+}$baseline levels (in $\mathrm{mM}$ ): predrug, 4.9 ; during drug, 4.7 ; recovery, $6.5 . \mathrm{K}^{+}, \mathrm{K}^{+}$responses recorded by "valinomycin" electrodes; $T M A^{+}, \mathrm{TMA}^{+}$responses recorded by "Corning" electrodes. Predrug, responses recorded prior to the superfusion of $\mathrm{Ba}^{2+} ; \mathrm{Ba}^{2+}$, responses during $\mathrm{Ba}^{2+}$ superfusion; Recovery, responses $2 \mathrm{hr}$ after removal of $\mathrm{Ba}^{2+}$ from superfusate. Calibration: $L E R G, 1.3$

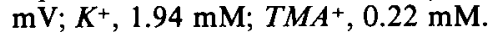

\section{$\mathrm{Ba}^{2+}$}

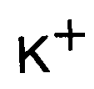

$\mathrm{TMA}^{+}$

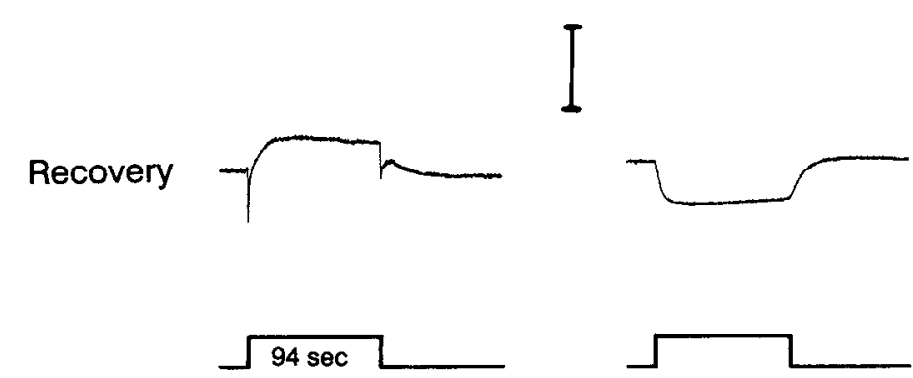

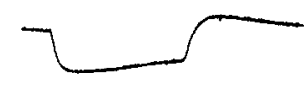
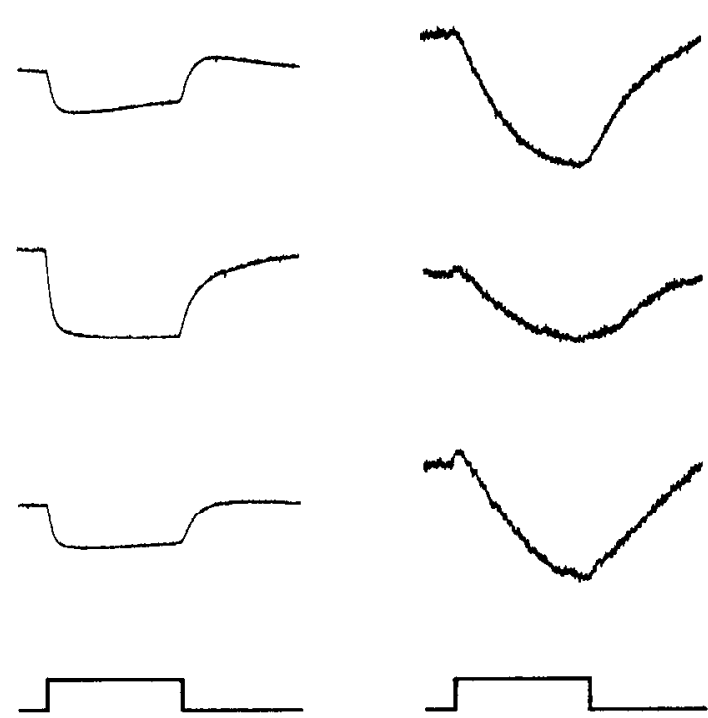


\section{LERG}
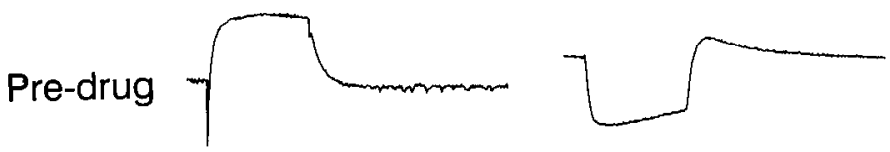

$I$

Amiloride
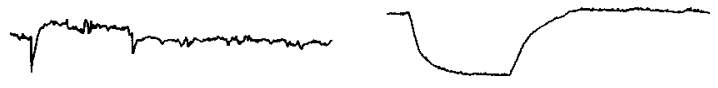

$\sqrt{94 \sec }$

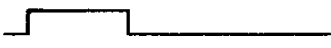

$\mathrm{TMA}^{+}$

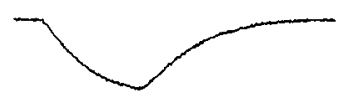

Figure 9. Effects of amiloride $(2.0 \mathrm{mM})$ on the light-evoked LERG, $\mathrm{K}^{+}$, and $\mathrm{TMA}^{+}$responses in the SRS. Superfusate $\left[\mathrm{TMA}^{+}\right]$was $10 \mathrm{mM}$. TMA ${ }^{+}$baseline levels in the SRS: predrug, $6.0 \mathrm{mM}$; during drug, $92 \mathrm{mM}$. The $\mathrm{TMA}^{+}$response did not recover at $2 \mathrm{hr}$ after removal of amiloride. Calibration: $L E R G$, $1.5 \mathrm{mV} ; K^{+}, 1.5 \mathrm{mM} ; T M A^{+}, 0.54 \mathrm{mM}$.
DIDS. The $\mathrm{Na}^{+}-\mathrm{HCO}_{3}{ }^{-}$cotransporter in PE cells is blocked by DIDS (4,4'-diisothiocyanostilbene-2,2'-disulfonate; Hughes et al., 1989). In other cells, this cotransport mechanism plays a role in volume regulation (Hoffmann and Simonsen, 1989). DIDS $(1.0 \mathrm{mM})$ was applied to three eyecups. In each case, the LERG b- and d-waves were blocked after 30 min application. However, the c-wave was slightly enhanced, and the $\mathrm{TMA}^{+}$response was little affected (Fig. 10). Thus, the $\mathrm{Na}^{+}-\mathrm{HCO}_{3}{ }^{-}$transport seems to play little role in the light-evoked increase of SRS volume.

Furosemide and bumetanide. The apical membrane of the PE cells contains a $\mathrm{Na}^{+}-\mathrm{K}^{+}-\mathrm{Cl}^{-}$cotransporter that is important for net $\mathrm{K}^{+}$and $\mathrm{Cl}^{-}$transport across the epithelium (Miller and Edelman, 1990) and for volume regulation of PE cells (Adorante and Miller, 1990). Furosemide and bumetanide block this cotransport in the PE, as well as in other cells.

Furosemide $(1.0 \mathrm{mM})$ was applied to three eyecups. In every case, the $b$ - and d-waves were blocked after $30 \mathrm{~min}$ application. However, the c-wave and the SRS TMA' decrease were both enhanced (Fig. 11). This result does not support the $\mathrm{Na}^{+}-\mathrm{K}^{+}-$ $\mathrm{Cl}^{-}$cotransporter being important in the light-evoked increase in SRS volume.

Bumetanide is a more potent and specific blocker of this cotransporter, and it blocks regulatory volume changes in PE cells (Adorante and Miller, 1990). Bumetanide (obtained as gift from Hoffman-LaRoche, Inc., Nutley, NJ) was applied in con-

\section{TMA $^{+}$}

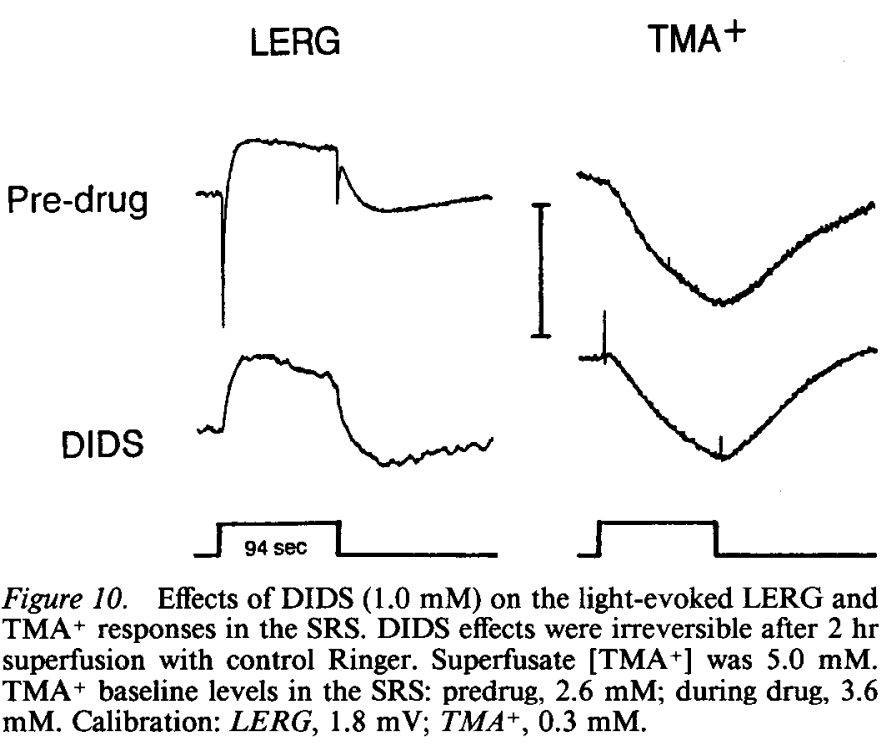

Figure 10. Effects of DIDS (1.0 mM) on the light-evoked LERG and TMA $^{+}$responses in the SRS. DIDS effects were irreversible after $2 \mathrm{hr}$ superfusion with control Ringer. Superfusate [TMA+] was $5.0 \mathrm{mM}$. TMA + baseline levels in the SRS: predrug, $2.6 \mathrm{mM}$; during drug, 3.6 mM. Calibration: $L E R G, 1.8 \mathrm{mV} ; T M A^{+}, 0.3 \mathrm{mM}$. centrations ranging from 0.05 to $0.10 \mathrm{mM}$. On some occasions, bumetanide had no effect on light-evoked retinal responses. Other times, particularly when $0.10 \mathrm{mM}$ was used, all retinal responses (LERG b- and c-waves, TMA+ decrease, and SRS K+ decrease) became depressed. This indicates that bumetanide depresses photoreceptor function, and therefore is not a suitable agent to use in the eyecup preparation.

\section{Discussion}

This article has shown that light induces a decrease in extracellular probe ion concentration in the SRS. We believe this decrease arises because of an expansion of the SRS, which results from a shrinkage of the PE cells. Before discussing the cellular mechanisms and significance of these changes, alternative explanations need to be considered.

Probe ion uptake. In this study, it was assumed that the probe ions remain in ECS, at least during the time of the measurement. Supporting this, Nicholson and Phillips (1981) found in rat cerebellum that these probe ions remain extracellular for at least $50 \mathrm{sec}$. If this situation holds for frog retina, then probe ion uptake should be slight in the present study, because the lightevoked decrease in probe ion concentration peaks at 70-90 sec. However, TMA ${ }^{+}$definitely enters leech neuropil glial cells (Ballanyi et al., 1990) and frog PE cells (Adorante and Miller, 1990), and the possibility must be considered that light enhances $\mathrm{TMA}^{+}$

\section{LERG}
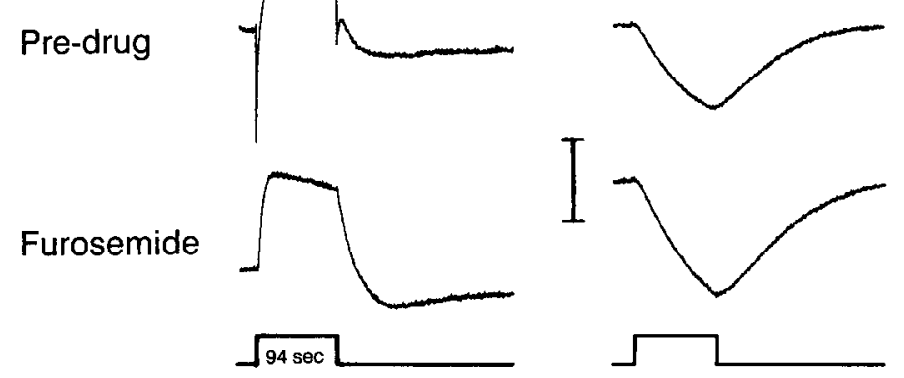

Figure 11. Effects of furosemide (1.0 mM) on the light-evoked LERG and TMA+ response in the SRS. Furosemide effects were irreversible after $2 \mathrm{hr}$ superfusion with control Ringer. Superfusate [TMA ${ }^{+}$] was 5.0 $\mathrm{mM}$. TMA+ baseline levels in SRS: predrug, $2.6 \mathrm{mM}$; during drug, 3.0 mM. Calibration: $L E R G, 0.9 \mathrm{mV} ; T M A^{+}, 0.17 \mathrm{mM}$. 
uptake into PE cells, thus resulting in decreased concentration in the SRS. Three results in the present study argue against this mechanism.

(1) The response polarity, amplitude, and time course were similar with two types of probe cations, and with two types of probe anions. To interpret this as being due to a light-evoked change in uptake, the cation and anion uptake mechanisms must be fairly tightly coupled. A cotransporter that accepted the four nonbiological probe cations and anions certainly would be unexpected. Also, because TMA ${ }^{+}$is thought to enter the PE cells through an organic cation pathway, and because cotransporters in the apical membrane of the PE cells are not involved in this process (Adorante and Miller, 1990), a coupling of uptake mechanisms for probe cations and anions seems unlikely.

(2) During prolonged illumination $(10 \mathrm{~min}),\left[\mathrm{TMA}^{+}\right]$shows substantial recovery toward its preillumination baseline level. Also, in chick the light-evoked TMA+ decrease dissipated within $5 \mathrm{~min}$ of light onset ( $\mathrm{Li}$ et al., 1992). This decrease and subsequent recovery of $\left[\mathrm{TMA}^{+}\right]$during light is readily explained by the SRS expanding and then TMA ${ }^{+}$diffusing from proximal retina to the SRS, thus reestablishing the baseline concentration. If there was a light-evoked increase in a $\mathrm{TMA}^{+}$uptake, then $\left[\mathrm{TMA}^{+}\right]$should remain reduced during long-duration illumination, as can be observed with $\left[\mathrm{K}^{+}\right]$in the SRS (Fig. 5).

(3) During light, SRS tissue resistance dropped to $91 \%$ of its baseline level. This is expected if SRS volume increases. Resistance could decrease if a larger proportion of the transretinal current passes intracellularly during illumination, but the idea seems unlikely and we have no evidence for it. Another possibility is that resistance decreases because light induces an increase in ionic strength in the SRS. However, during prolonged illumination, $\left[\mathrm{K}^{+}\right]$and $\left[\mathrm{Ca}^{2+}\right]$ decrease (Livsey et al., 1990), while changes in $\left[\mathrm{Na}^{+}\right]$and $\left[\mathrm{Cl}^{-}\right]$are uncertain.

Overall, these observations rather strongly support the idea that light induces an increase in SRS volume. We believe this volume increase is caused by a shrinkage of PE cell volume, but one other alternative explanation must be considered: the SRS volume increase might arise because of retinomotor movements. For example, during a light flash, the contracting rods might pull away from the PE cells, thus increasing SRS volume. However, the time course for retinomotor movements is very slow in teleosts (Burnside et al., 1983), with $>30$ min required for the maximum response, even after a brief light flash (Muntz and Richard, 1982). The timing in frog is less certain, but pigment granule migration in frog PE cells is maintained for up to $6 \mathrm{hr}$ after light onset, even if the light was turned off (Mondragon and Frixione, 1989). On the other hand, the probe ion responses are faster (time-to-peak and time-to-decay around $80 \mathrm{sec}$ ), and the probe ion responses can be repetitively elicited. Thus, retinomotor movements are unlikely to underlie the SRS volume changes.

Interfering ions and response amplitude. Electrode calibrations showed that the light-evoked $\mathrm{TMA}^{+}$responses were not contaminated by the SRS $\mathrm{K}^{+}$decrease. Further supporting this is the observation that the time course of the $\mathrm{TMA}^{+}$decrease was significantly slower than the SRS $\mathrm{K}^{+}$decrease. However, the amplitude of the light-evoked probe ion decrease likely does underestimate the magnitude of the increase in SRS volume. This is because the time course of the SRS expansion is relatively slow, and the probe ion decrease in the SRS will be continuously countered by the diffusion of probe ions from locations proximal and distal to the SRS. Although we have not tried to use diffusion kinetics to estimate the largest possible SRS volume change, we believe the volume increase is not much greater than we reported here, because the resistance measurements show a decrease of only $9 \%$.

Cellular mechanism of SRS volume change. Because no lightevoked decrease in probe ion concentration was measured around the photoreceptor outer segments in the isolated retina, it is likely that the PE cells are involved in the generation of the SRS volume change in eyecups. An important role for the $\mathrm{PE}$ is also supported by the work of Adorante and Miller (1990), who found that isolated PE cells undergo appropriate volume changes when $\left[\mathrm{K}^{+}\right]_{0}$ is shifted within the physiological range $(2-5 \mathrm{mM})$.

The membrane mechanisms of the PE cells that are important for the SRS volume change are probably located in the apical membrane, because it is this side that faces the SRS. Four apical membrane transport mechanisms have been shown to be actively involved in transepithelial fluid transport: the $\mathrm{K}^{+}$conductance, the $\mathrm{Na}^{+}-\mathrm{H}^{+}$exchanger, and the $\mathrm{Na}^{+}-\mathrm{HCO}_{3}{ }^{-}$and $\mathrm{Na}^{+}-\mathrm{K}^{+}-\mathrm{Cl}^{-}$cotransporters (Joseph and Miller, 1991). In the present study, use of blocking agents provided no evidence that either cotransporter plays an important role in the SRS volume change. On the other hand, $\mathrm{Ba}^{2+}\left(\mathrm{K}^{+}\right.$channel blocker $)$and amiloride (blocker of the $\mathrm{Na}^{+}-\mathrm{H}^{+}$exchanger) both depressed the SRS TMA ${ }^{+}$decrease, thus suggesting a role for these two membrane mechanisms. Perhaps the light-evoked SRS K ${ }^{+}$decrease results in $\mathrm{K}^{+}$movement out of the PE cells, through the $\mathrm{Ba}^{2+}$ sensitive $\mathrm{K}^{+}$channels (LaCour et al., 1986; Hughes and Steinberg, 1990). To maintain approximate electrical balance, $\mathrm{Cl}^{-}$ might exit the PE cells via the DIDS-sensitive $\mathrm{Cl}^{-}$channels located on the basal membrane (Gallemore and Steinberg, 1989). (The ineffectiveness of DIDS in the present study may be because the superfusate, which was applied to the retinal surface, could not reach the basal membrane.) The net loss of $\mathrm{K}^{+}$and $\mathrm{Cl}^{-}$would then bring water out of the PE cells, thus leading to their shrinkage and a concomitant expansion of SRS volume. The role of the amiloride-sensitive $\mathrm{Na}^{+}-\mathrm{H}^{+}$exchanger in the PE cell shrinkage is more speculative and has been described in Huang (1991).

Adorante and Miller (1990) showed that after initial osmotic shrinkage by mannitol, isolated PE cells undergo a regulatory volume increase mediated by a $\mathrm{Na}^{+}-\mathrm{K}^{+}-\mathrm{Cl}^{-}$cotransporter in the apical membrane. Results with furosemide in the present study do not support this, but the best blocker of the cotransporter (bumetanide) did not provide any interpretable results. It is also possible that this cotransporter mediates the subsequently activated volume regulatory processes, rather than the initial PE cell volume changes such as those expected from the present study. On the other hand, in chick retina, results with furosemide and bumetanide support the role of this cotransporter in the SRS volume increase ( $\mathrm{Li}$ et al., 1992).

Significance of the SRS volume change. This study measured the normal, activity-dependent (light-evoked) ECS volume changes in situ in a CNS tissue (retina). Adorante and Miller (1990) reported that isosmotic elevation of apical $\left[\mathrm{K}^{+}\right]_{0}$ from 2.0 to $5.0 \mathrm{mM}$ caused PE cells to swell by about $7 \%$. Because this increase in $\left[\mathrm{K}^{+}\right]_{o}$ is similar in amplitude to the increase measured in the SRS of the eyecup-retina during a light-to-dark transition (Oakley and Green, 1976), this $\left[\mathrm{K}^{+}\right]_{o}$-induced PE cell swelling is compatible with the results of the present study, in both amplitude and time course. The light-evoked changes in the PE and SRS volume may be important in retina-PE adhesivity (Marmor, 1989), in interactions such as phagocytosis 
between the PE cells and photoreceptors (Adorante and Miller, 1990), and in the differential distribution of the interphotoreceptor matrix during prolonged light and dark (Uehara et al., 1990)

The SRS volume change will certainly influence the extracellular concentrations of various solutes. In fact, all published measurements of light-evoked changes in substances in the SRS contain a component that is caused by the SRS volume change. For example, Figure 12 shows the change in SRS volume, measured with $\mathrm{TMA}^{+}$, plotted with experimentally recorded $\mathrm{K}^{+}$ and $\mathrm{Ca}^{2+}$ responses. The change in SRS volume was subtracted from the $\mathrm{K}^{+}$and $\mathrm{Ca}^{2+}$ responses to yield "corrected responses." This subtraction was done using the relation

$$
\text { Corrected [ion }]_{o} \times(1+\Delta \mathrm{SRS}),
$$

where $\triangle$ SRS is the percentage change in SRS volume relative to baseline, and [ion] is the extracellular ionic concentration (either $\mathrm{K}^{+}$or $\mathrm{Ca}^{2+}$ ). The "corrected responses" show how these ions would vary if the SRS volume change did not occur. (Similar results were also obtained with $\mathrm{AsF}_{6}^{-}$; see Fig. 25 of Huang, 1991). Because the recorded SRS $\mathrm{K}^{+}$decrease is large, the corrected $\mathrm{K}^{+}$response is only slightly different: it is a little smaller, and the reaccumulation of $\mathrm{K}^{+}$during prolonged illumination is stronger.

In contrast, the light-evoked change in $\left[\mathrm{Ca}^{2+}\right]$ in the SRS is a small response, and the SRS volume change exerts a major effect on it. The $\mathrm{Ca}^{2+}$ response at light onset in the SRS of an eyecup consists of an initial increase, followed by a slower decrease to a level below the preillumination baseline (Livsey et al., 1990). At light offset, $\left[\mathrm{Ca}^{2+}\right]$ gradually returns to baseline. The slow decrease below baseline during light is not seen in the corrected response (Fig. 12), and it is likely caused by the lightevoked increase in SRS volume. Supporting this conclusion is that $\mathrm{Ca}^{2+}$ fluxes during light are only outward across rod outer segments (Miller and Korenbrot, 1987), and only a light-evoked increase in $\left[\mathrm{Ca}^{2+}\right]_{0}$ is observed in the vicinity of the outer segments in the retina isolated from the PE cells (Gold and Korenbrot, 1980; Yoshikami et al., 1980; Govardovskii et al., 1987; Livsey et al., 1990). These latter studies, especially that of Livsey et al. (1990), which was performed in our lab with a preparation and light stimuli identical to those used in the present study, also support the conclusion that the $\mathrm{PE}$ cells are responsible for the light-evoked increase in SRS volume.

The absolute value of SRS volume is uncertain, but in frog it has been estimated at $12 \%$ (Karwoski et al., 1985). In the present study, if light causes an expansion of SRS volume by $9 \%$, then the absolute value of SRS increases only $1.1 \%$, from $12 \%$ to $13.1 \%$. Because PE cell volume is relatively large, only a slight light-evoked shrinkage of the PE cells would be neccssary to result in this SRS volume change. Adorante and Miller (1990) showed in isolated PE cells that raising $\left[\mathrm{K}^{+}\right]_{o}$ from 2.0 to $5.0 \mathrm{mM}$ caused a $7 \%$ increase in cell volume. In our experiments in the eyecup-retina, light causes SRS $\left[\mathrm{K}^{+}\right]$to decrease from $2.5 \mathrm{mM}$ to about $1.5 \mathrm{mM}$. A change in $\left[\mathrm{K}^{+}\right]_{o}$ of this magnitude $(1.0 \mathrm{mM})$ should cause only a fraction of the change in PE cell volume measured by Adorante and Miller (1990) when they varied $\left[\mathrm{K}^{+}\right.$] by $3.0 \mathrm{mM}$. The relative volume and surface area of the PE cell membranes in the SRS region are uncertain, but substantial. Thus, it seems that the change in PE cell volume could account for the change in SRS volume, but this will have to be shown quantitatively. Also, it will be interesting to measure PE cell volume changes in eyecup-retinas and
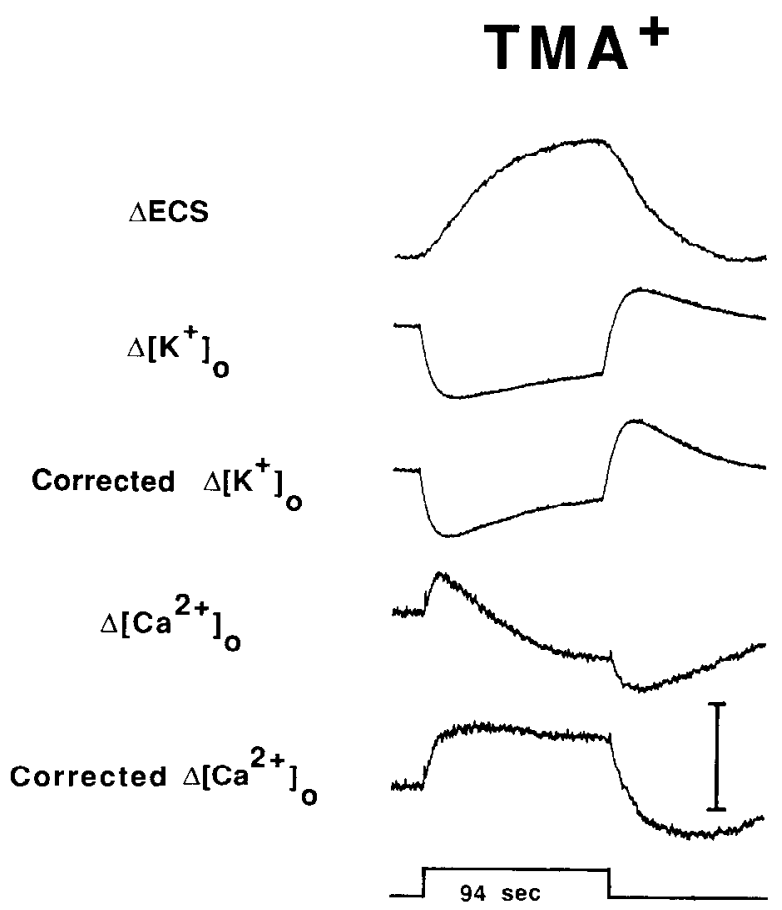

Figure 12. Effects of light-evoked changes in SRS volume, measured by $\mathrm{TMA}^{+}$, on the $\mathrm{K}^{+}$and $\mathrm{Ca}^{2+}$ responses recorded in the SRS. $\triangle \mathrm{ECS}$ was determined from the $\mathrm{TMA}^{+}$response. With the use of Equation 2, $\triangle E C S$ was subtracted from the experimentally recorded $\mathrm{K}^{+}$and $\mathrm{Ca}^{2+}$ responses $\left(\Delta / \mathrm{K}^{+}\right]_{0}$ and $\left.\left.\Delta / \mathrm{Ca}^{2+}\right]_{0}\right)$ in the SRS to yield "corrected responses." Baseline levels: $\left[\mathrm{K}^{+}\right], 2.5 \mathrm{mM} ;\left[\mathrm{Ca}^{2+}\right], 1.8 \mathrm{mM}$. Calibration: $\triangle E C S, 5 \% ; \mathrm{K}^{+}$responses (experimental and corrected), $0.5 \mathrm{mM} ; \mathrm{Ca}^{2+}$ responses, $0.09 \mathrm{mM}$.

compare these to the measurements in isolated PE cells-changes in $\mathrm{PE}$ cell volume in response to light-evoked changes in [ $\left.\mathrm{K}^{\prime}\right]_{o}$ might be altered by the simultaneous occurrence of other processes.

\section{References}

Adorante JS, Miller SS (1990) Potassium-dependent volume regulation in retinal pigment epithelium is mediated by $\mathrm{Na}, \mathrm{K}, \mathrm{Cl}$ cotransport. J Gen Physiol 96:1153-1176.

Ballanyi K, Grafe P, Serve G, Schlue W-R (1990) Electrophysiological measurements of volume changes in lecch neuropile glial cells. Glia $3: 151-158$

Burnside B, Adler R, O'Connor P (1983) Retinomotor pigment migration in the teleost retinal pigment epithelium. I. Roles for actin and microtubules in pigment granule transport and cone movement. Invest Ophthalmol Vis Sci 24:1-15.

Dietzel I, Heinemann U, Hofmeier G, Lux HD (1980) Transient changes in the size of the extracellular space in the sensorimotor cortex of cats in relation to stimulus-induced changes in potassium concentration. Exp Brain Res 40:432-439.

DoCarmo RJ, Martins-Ferreira H (1984) Spreading depression of I eao probed with ion-selective microelectrodes in isolated chick retina. An Acad Bras Cienc 56:401-421.

Gallemore RP, Steinberg RH (1989) Effects of DIDS on the chick retinal pigment epithelium. I. Mcmbranc potential, apparent resistances, and mechanisms. J Neurosci 9:1968-1976.

Gold GH, Korenbrot JI (1980) Light-induced calcium release by intact retinal rods. Proc Natl Acad Sci USA 77:5557-5561.

Govardovskii VI, Bykov KA, Skachkov SN (1987) Light-induced calcium release from retinal photoreceptors, and "calcium hypothesis" of visual excitation. Biol Membr 4:600-612.

Griff ER, Shirao Y, Steinberg RH (1985) $\mathrm{Ba}^{2+}$ unmasks $\mathrm{K}^{+}$modulation of the $\mathrm{Na}^{+}-\mathrm{K}^{+}$pump in the frog retinal pigment epithelium. J Gen Physiol 86:853-876. 
Hoffmann EK, Simonsen LO (1989) Membrane mechanisms in volume and $\mathrm{pH}$ regulation in vertebrate cells. Physiol Rev 69:315-382.

Huang B (1991) Light-evoked changes in subretinal space (SRS) volume in the retina of frog (Rana pipiens). PhD thesis, University of Georgia at Athens.

Huang B, Karwoski CJ (1989) Changes in extracellular space in the frog retina. Invest Ophthalmol Vis Sci [Suppl] 30:64.

Huang B, Karwoski CJ (1990) Light-evoked increase in subretinal space (SRS) in frog retina. Invest Ophthalmol Vis Sci [Suppl] 31:71.

Hughes BA, Steinberg RH (1990) Voltage-dependent currents in isolated cells of the frog retinal pigment epithelium. J Physiol (Lond) 428:273-297.

Hughes BA, Adorante JS, Miller SS, Lin H (1989) Apical electrogenic $\mathrm{NaHCO}_{3}$ absorption across the retinal pigment epithelium. J Gen Physiol 94:125-150.

Joseph DD, MillerSS (1991) Apical and basal membrane ion transport mechanisms in bovine retinal pigment epithelium. J Physiol (Lond) 435:439-463.

Karwoski CJ, Frambach DA, Proenza LM (1985) Laminar profile of resistivity in frog retina. J Neurophysiol 54:1607-1619.

Karwoski CJ, Lu H-K, Newman EA (1989) Spatial buffering of lightevoked potassium increases by retinal Müller (glial) cells. Science 244: 578-580.

LaCour M, Lund-Andersen H, Zeuthen T (1986) Potassium transport of the frog retinal pigment epithelium: autoregulation of potassium activity in the subretinal space. J Physiol (Lond) 375:461-479.

Li J-D, Gallemore RP, Steinberg RH (1992) Light-evoked increase in subretinal space volume in chick retina. Invest Ophthalmol Vis Sci [Suppl] 33:913.

Livsey CT, Huang B, Xu J, Karwoski CJ (1990) Light-evoked changes in extracellular calcium concentration in frog retina. Vision Res 30 : 853-861.

Marmor ME (1989) Mechanisms of normal retinal adhesion. In: The retina, Vol 3 (Ryan SJ, ed), pp 71-87. St. Louis: Mosby.

Miller DL, Korenbrot JI (1987) Kinetics of light-dependent Ca fluxes across the plasma membrane of rod outer segments. J Gen Physiol 90:397-425.

Miller SS, Edelman JL (1990) Active ion transport pathways in the bovine retinal pigment epithelium. J Physiol (Lond) 424:283-300.

Mondragon R, Frixione E (1989) Retinomotor movements in the frog retinal pigment epithelium: dependence of pigment migration on $\mathrm{Na}^{+}$ and $\mathrm{Ca}^{2+}$. Exp Eye Res 48:589-603.

Muntz WRA, Richard DS (1982) Photomechanical movements in the trout retina following brief flashes of light. Vision Res 22:529-530.
Newman EA (1989) Potassium conductance block by barium in amphibian Müller cells. Brain Res 498:308-314.

Nicholson C, Hounsgard J (1983) Diffusion in the slice microenvironment and implications for physiological studies. Fed Proc 42: 2865-2868.

Nicholson C, Phillips JM (1981) Ion diffusion modified by tortuosity and volume fraction in the extracellular microenvironment of the rat cerebellum. J Physiol (Lond) 321:225-257.

Oakley B, Green DG (1976) Correlation of light-induced changes in retinal extracellular potassium concentration with c-wave of the electroretinogram. J Neurophysiol 39:1117-1133.

Oakley B, Katz BJ, Xu Z, Zheng J (1991) Müller cell spatial buffering currents transport potassium to distal retina. Invest Ophthalmol Vis Sci 32:672.

Orkand RK, Dietzel I, Coles JA (1984) Light-induced changes in extracellular volume in the retina of the drone, Apis mellifera. Neurosci Lett 45:273-278.

Phillips JM, Nicholson C (1979) Anion permeability in spreading depression investigated with ion-sensitive microelectrodes. Brain Res 173:567-571.

Svoboda J, Sykova E (1989) Activity-related extracellular $\mathrm{K}^{+}$and volume changes in spinal cord of the rat. Acta Physiol Scand 136[Suppl $582]: 86$.

Svoboda J, Sykova E (1991) Extracellular space volume changes in the rat spinal cord produced by nerve stimulation and peripheral injury. Brain Res 560:216-224.

Uehara F, Matthes MT, Yasumura D, LaVail MM (1990) Light-evoked changes in the interphotoreceptor matrix. Science 248:1633-1636.

Van Harreveld A, Khattab F (1967) Changes in cortical extracellular space during spreading depression investigated with electron microscope. J Neurophysiol 30:911-929.

Vogel DA (1980) Potassium release and ERG b-wave current flow in the frog retina. PhD thesis. Ann Arbor : University of Michigan.

Xu X, Xu J, Huang B, Livsey CT, Karwoski CJ (1991) Comparison of pharmacological agents (aspartate vs. aminophosphonobutyric plus kynurenic acids) to block synaptic transmission from retinal photoreceptors in frog. Exp Eye Res 52:691-698.

Yoshikami S, George JS, Hagins WA (1980) Light-induced calcium fluxes from outer segment layer of vertebrate retinas. Nature 286 : 395-398.

Ziegler A, Walz B (1989) Analysis of extracellular calcium and volume changes in the compound eye of the honeybee drone, Apis mellifera. J Comp Physiol A 165:697-709. 